\title{
Low Magnesium with High Potassium Supply Changes Sugar Partitioning and Root Growth Pattern Prior to Visible Magnesium Deficiency in Leaves of Rice (Oryza sativa L.)
}

\author{
Yuchuan Ding ${ }^{*}$, Guohua $\mathrm{Xu}^{2}$ \\ ${ }^{1}$ Institute of Agricultural Environment and Resources, Shanxi Academy of Agricultural Sciences, Taiyuan, China; ${ }^{2}$ College of Re- \\ sources and Environmental Sciences, Nanjing Agricultural University, Nanjing, China. \\ Email: ${ }^{*}$ dychuan@163.com
}

Received July $23^{\text {th }}, 2011$; revised September $8^{\text {th }}, 2011$; accepted September $20^{\text {th }}, 2011$.

\begin{abstract}
This research was conducted to investigate the effects of low magnesium $(\mathrm{Mg})$ with high potassium $(\mathrm{K})$ supply on the Mg concentration, sugar partitioning and root growth of rice (Oryza Sativa L. cv. Wuyunjing 7) plants grown in hydroponics under greenhouse conditions, at Nanjing Agricultural University, China. The nutrient solution contained 0.01 and $1.0 \mathrm{mM} \mathrm{Mg}$ concentration, with K at 1.0 and $6.0 \mathrm{mM}$. Compared with the control ( $1 \mathrm{mM} \mathrm{Mg}$ and K) treatment, the soluble sugar content at the treatment of low $\mathrm{Mg}(0.01 \mathrm{mM})$ with high $K(6 \mathrm{mM})$ decreased by $35.7 \%$ in leaves, whereas increased $29.2 \%$ in roots at day 15 after treatment initiation. The shoot dry weight $(D W)$ declined $12.9 \%$, but root DW increased $12.1 \%$ leading to the significant increase in the root to shoot ratio at day 30 . Furthermore, the total root length, total root surface area, root volume, average root diameter, total length of $0-0.5 \mathrm{~mm}$ and $0.5-1.0 \mathrm{~mm}$ diameter roots at day 30 significantly increased by $11.8 \%, 16.4 \%, 25.3 \%, 8.1 \%, 16.6 \%$ and $12.5 \%$, respectively. Correlation analysis revealed the root to shoot ratio is closely related to the soluble sugar contents in roots and root morphological parameters of rice at day 15 and day 30. The typical visible symptoms of Mg deficiency in leaves of rice were obtained in the treatment of low Mg with high $\mathrm{K}$ at day 35. These findings indicated that low Mg with high K supply altered sugar partitioning and root morphological parameters, resulting in the increased root to shoot ratio prior to visible Mg deficiency symptoms in rice leaves. The increase in root to shoot ratio maybe an important adaptive mechanism for rice plants to respond to low-Mg stress during the early growth stage.
\end{abstract}

Keywords: Magnesium, Potassium, Sugar Partitioning, Root Growth Parameter, Rice

\section{Introduction}

Magnesium $(\mathrm{Mg})$ is one of the essential mineral nutrients for the growth and development of plants. Apart from being a central atom of the chlorophyll molecule, $\mathrm{Mg}$ also acts as activator or regulator of many key enzymes in plant physiological processes [1,2]. Both $\mathrm{Mg}$ deficiency and oversupply have detrimental effects on plant photosynthesis [3], consequently resulting in abnormal or restricted growth of plants [2].

With the introduction of high-yielding varieties, the heavy application of nitrogen $(\mathrm{N})$, phosphorus $(\mathrm{P})$ and potassium $(\mathrm{K})$ fertilizers, the amplified rotations per site and the continuous intensive harvesting of crop productions without recycling crop residues or replacing with mineral fertilizers, the Mg depletion in soils is increasing [4]. Consequently, many light-textured soils have been shown to exhibit Mg deficiencies, particularly in highly weathered acid soils with high percolation rates and leaching losses. Mg deficiency can be caused not only by small concentrations of the nutrient in a soil but also by ionic antagonism, particularly in acid and K-rich soils. The cation competitive effects frequently lead to $\mathrm{Mg}$ deficiency in the field [5]. Mg deficiency in plants occurs worldwide influencing productivity and quality in agriculture [4].

Plant growth and development depend highly on environmental conditions, such as temperature, light intensity and availability of water and essential mineral nutrients 
[6]. Mineral nutrients possess several roles in formation, partitioning, and utilization of photosynthates. Therefore, mineral nutrient deficiencies substantially impair production of dry matter and its partitioning between the plant organs [7]. Mg deficiency has been reported to affect plant growth and biomass partitioning between root and shoot [4]. Under Mg deficiencies root growth markedly decreased, leading to an increase in shoot to root dry weight (DW) ratios in plants [8-11].

Despite numerous studies examining the effects of $\mathrm{Mg}$ deficiency on plant development and biomass allocation, very little information is known about the influence of Mg stress on plant biomass allocation before the symptoms of $\mathrm{Mg}$ deficiency appear in leaves of plants, especially in field crops. The present investigation was implemented to study the interaction between $\mathrm{Mg}$ and $\mathrm{K}$ in relation to their effects on the uptake and translocation of $\mathrm{Mg}$, soluble sugar partitioning and root growth parameters during the early growth stage of rice (Oryza sativa L.), one of the most important food crops for large world population [12]. In this study, we found that under $\mathrm{Mg}$ stress induced by low Mg with high $\mathrm{K}$ supply, rice changes its soluble sugar partitioning and root growth parameters leading to an increase in root to shoot DW ratio before visible $\mathrm{Mg}$ deficiency symptoms occur in the leaves of rice plants. With increasing $\mathrm{Mg}$ deficiency, the root to shoot ratio was gradually decline, mainly because of impaired photosynthesis and export of carbohydrates from the leaves to roots of rice.

\section{Materials and Methods}

\subsection{Plant Material and Cultivation}

Rice (Oryza sativa L. cv. Wuyunjing-7) plants were grown in hydroponics culture under greenhouse conditions at Nanjing Agricultural University, Nanjing, China. The maximum light intensities at the experimental site ranged from 1100 to $1450 \mu \mathrm{mol} \cdot \mathrm{m}^{-2} \cdot \mathrm{s}^{-1}$ at $12: 00$ noon, maximum and minimum temperature during this period ranged $30^{\circ} \mathrm{C}-35^{\circ} \mathrm{C}$ at daytime and $20^{\circ} \mathrm{C}-22.5^{\circ} \mathrm{C}$ at night. The relative humidity ranged from $65 \%$ to $75 \%$. Seeds of rice were washed thoroughly and disinfected in $10 \%$ $\mathrm{H}_{2} \mathrm{O}_{2}$ for 20 min followed by five washes with deionized water. Seeds of uniform size were imbibed overnight and germinated in a solution in a plastic box in a growth chamber $(16 \mathrm{~h}$ light $/ 8 \mathrm{~h}$ dark, day/night temperature of $28 / 22^{\circ} \mathrm{C}$, and $65 \%-70 \%$ relative humidity). The uniform 20d-old seedlings (two-leaf stage) were transplanted into a $5 \mathrm{~L}$ plastic container. The box had 12 holes in the lid (two seedlings per hole). The transplanted rice seedlings had been grown at one-fifth strength of full nutrient solution for two weeks prior to the beginning of the treat- ments. The nutrient solusion, based on Yoshida et al., 1972 [13], contained nutrients at the following concentrations (in $\mu \mathrm{M}$ ): $1000\left(\mathrm{NH}_{4}\right)_{2} \mathrm{SO}_{4} ; 1000 \mathrm{Ca}\left(\mathrm{NO}_{3}\right)_{2} ; 1000$ $\mathrm{NaH}_{2} \mathrm{PO}_{4} ; 1000 \mathrm{MgSO}_{4} \cdot 7 \mathrm{H}_{2} \mathrm{O} ; 1000 \mathrm{KCl} ; 2000 \mathrm{Na}_{2}-$ $\mathrm{SiO}_{3} \cdot 9 \mathrm{H}_{2} \mathrm{O} ; 0.5 \quad \mathrm{MnSO}_{4} \cdot \mathrm{H}_{2} \mathrm{O} ; 10.0 \quad \mathrm{H}_{3} \mathrm{BO}_{3} ; 1.0 \mathrm{Zn}-$ $\mathrm{SO}_{4} \cdot 7 \mathrm{H}_{2} \mathrm{O} ; 0.1 \mathrm{CuSO}_{4} \cdot 5 \mathrm{H}_{2} \mathrm{O} ; 0.05\left(\mathrm{NH}_{4}\right)_{6} \mathrm{Mo}_{7}-\mathrm{O}_{24} \cdot 4 \mathrm{H}_{2} \mathrm{O}$; 20.0 FeNaEDTA. All nutrients were made with the AR grade salts in deionized water. The average $\mathrm{pH}$ of the solutions was daily controlled and maintained at $5.8 \pm$ 0.1 . The deionized water was added to the container daily to replace water loss by transpiration. The nutrient solutions were replaced every three days. The electrical conductivity (EC) of the nutrient solution was maintained below $2.0 \mathrm{dS} \cdot \mathrm{m}^{-1}$. At the beginning of the third week after transplanting, the concentrations of $\mathrm{Mg}$ and $\mathrm{K}$ in the culture solutions were adjusted to: 0.01 (low level) and $1.0 \mathrm{mM}$ (normal level as control) of $\mathrm{Mg}$ and to: 1.0 (normal level) and $6.0 \mathrm{mM}$ (high level) of $\mathrm{K}$, for a total of four treatments $\left(\mathrm{Mg}_{0.01} \mathrm{~K}_{1}, \mathrm{Mg}_{0.01} \mathrm{~K}_{6}, \mathrm{Mg}_{1} \mathrm{~K}_{1}, \mathrm{Mg}_{1} \mathrm{~K}_{6}\right)$. Each treatment was replicated three times in a completely randomized design (CRD).

\subsection{Chemical Analysis of Plant Tissue}

Plants were harvested at day 15 (seven-leaf stage), 30 (nine-leaf stage) and 40 (eleven-leaf stage) after treatment initiation. At each harvest, the plants were divided into shoots and roots. The roots were washed by tap water and cleaned with distilled water. The plant material for determination of dry weight and mineral analysis was dried in a forced air oven for $48 \mathrm{~h}$ at $70^{\circ} \mathrm{C}$. K concentrations were determined by flame emission photometry (FEP). Mg concentrations were assayed by atomic absorption spectrometry (AAS) after wet digestion in a block digester using an $\mathrm{H}_{2} \mathrm{SO}_{4}-\mathrm{H}_{2} \mathrm{O}_{2}$ solution [14].

\subsection{Measurement of Root Morphological Parameters}

At each harvest, root samples were scanned using the Win-RHIZO system (Regent Instruments, Inc., Quebec, Canada) on a LA 1600 scanner. Roots were spread into a single layer on a transparent tray with a small quantity of water, and then scanned and analyzed automatically by the software [15].

\subsection{Soluble Sugar Determination}

$0.2 \mathrm{~g}$ fresh leaves $(0.5 \mathrm{~g}$ for roots) were extracted with 10 $\mathrm{ml}$ deionized water for $30 \mathrm{~min}$ at $100^{\circ} \mathrm{C}$. The extraction was repeated five times. Supernatants were filtrated and collected to a volume of $50 \mathrm{ml}$ tube. Soluble sugar contents in fresh leaves and roots were determined according to Ding et al., 2006 [16]. 


\subsection{Statistical Analyses}

The results were examined by analysis of variance (ANOVA) with the statistical software SAS (V. 9.0) for windows (SAS Institute Inc., Cary, NC. USA). Differences between means of treatments were compared using the Fisher's least significant difference (LSD) at the 0.05 and 0.01 probability levels.

\section{Results}

\subsection{Visible Symptoms of Magnesium Deficiency}

Rice plants in the treatment of $\mathrm{Mg}_{0.01} \mathrm{~K}_{6}$ did not produce visible symptoms of $\mathrm{Mg}$ deficiency until at day 35 after treatment initiation. The typical visible symptoms of $\mathrm{Mg}$ deficiency in rice leaves have been previously described [16]. Since the rice seedlings had been grown in one fifth of full nutrient solution (containing $0.2 \mathrm{mM} \mathrm{Mg}$ ) for two weeks prior to treatment initiation, the initial accumulated $\mathrm{Mg}$ and its internal recycling in the seedlings attenuated the visible signs of Mg deficiency.

\subsection{Magnesium Concentrations in Shoot and Root}

With increasing concentration of $\mathrm{Mg}$ in the nutrient solution, $\mathrm{Mg}$ content in shoots of rice plants significantly increased at day 15, 30 and 40 after treatment (Figure 1(a)). Compared with the treatments of $\mathrm{Mg}_{1} \mathrm{~K}_{1}, \mathrm{Mg}$ content in shoot of the $\mathrm{Mg}_{0.01} \mathrm{~K}_{6}$ treatment remarkably decreased. At day 40 after treatment, the $\mathrm{Mg}$ concentrations in shoots of the $\mathrm{Mg}_{0.01} \mathrm{~K}_{6}$ treatment were much lower $\left(0.63 \mathrm{mg} \cdot \mathrm{g}^{-1} \mathrm{DW}\right)$ and clearly below the critical defi-

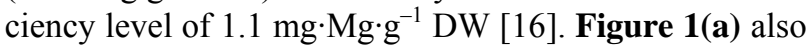
shows that high $\mathrm{K}$ supply (6 $\mathrm{mM} \mathrm{K}$ ) significantly restrained Mg uptake at different $\mathrm{Mg}$ supply levels from 0.01 to $1 \mathrm{mM} \mathrm{Mg}$, demonstrating a strong antagonistic effect between $\mathrm{Mg}$ and $\mathrm{K}$. The $\mathrm{Mg}$ content in roots showed the same trend as for shoots (Figure 1(b)). The ANOVA results suggested that both $\mathrm{K}$ and $\mathrm{Mg}$ concentrations and their interaction had a significant effect on the $\mathrm{Mg}$ contents in both shoots and roots of rice plants.

\subsection{Magnesium Translocation}

Similarly to the Mg contents in shoots and roots of rice plants, Mg uptake in shoots and roots significantly increased with increasing concentration of $\mathrm{Mg}$ in the nutrient solution after treatment initiation (result not shown).

The translocation of $\mathrm{Mg}$ was quantified by dividing the amount of the $\mathrm{Mg}$ accumulated in the shoots by the total amount of $\mathrm{Mg}$ taken up in the shoots and roots [17]. The result showed that the rate of $\mathrm{Mg}$ translocation from the root to the shoot of $\mathrm{Mg}_{0.01} \mathrm{~K}_{6}$ treatment maintained a higher level as compared with that of the $\mathrm{Mg}_{1} \mathrm{~K}_{1}$ treat-

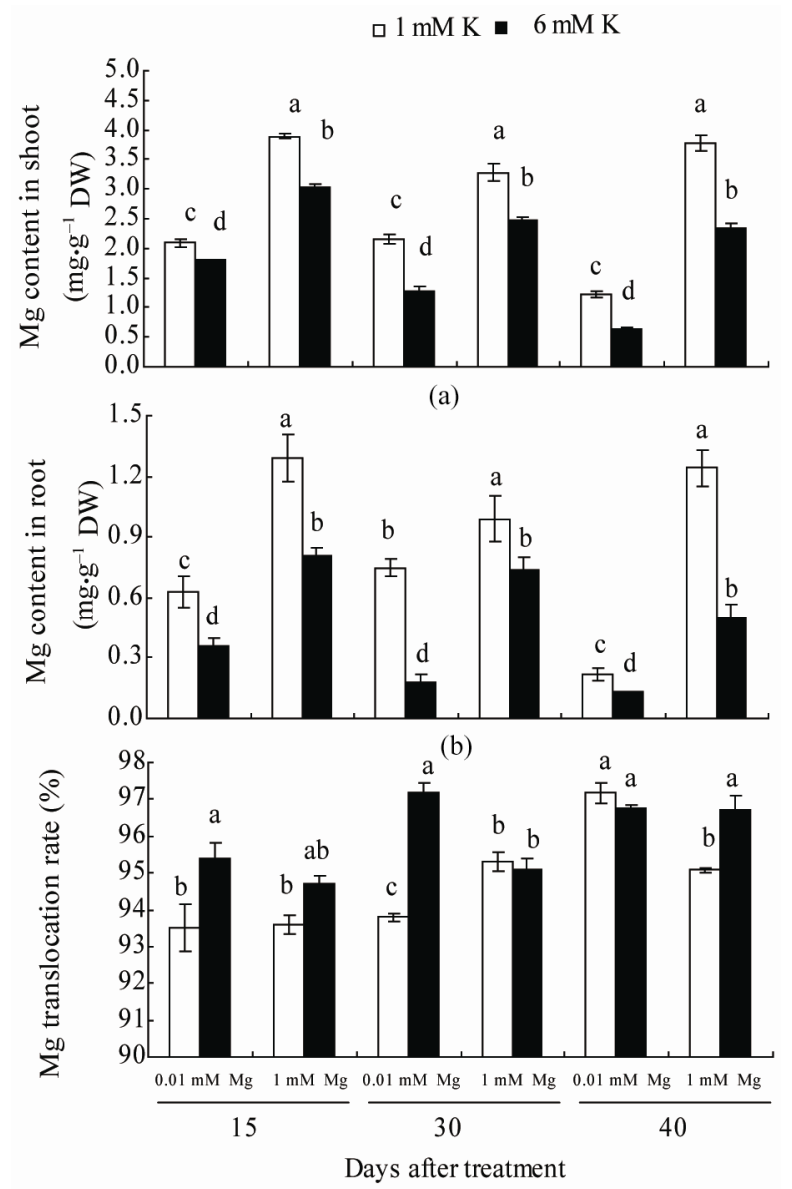

(c)

Figure 1. Effects of the interaction between $\mathrm{Mg}$ and $\mathrm{K}$ on the Mg contents in shoot (a) and root (b) and the rate of $\mathrm{Mg}$ translocation from the root to the shoot (c) of rice plants after treatment initiation. The nutrient solution contained 0.01 and $1.0 \mathrm{mM} \mathrm{Mg}$ concentration, with $\mathrm{K}$ at 1.0 and 6.0 $\mathrm{mM}$. The vertical bars are the standard error of means of three replicates. Bars with the same small letters at the same harvest mean not significantly difference between treatments by the least significant difference (LSD) at the 0.05 probability level. $\mathrm{Mg}$, magnesium; K, potassium; DW, dry weight.

ment at day 15, 30 and 40 after treatment initiation. This result indicated that increased $\mathrm{Mg}$ translocation from the root to the shoot may be an adaptive response of rice plants to the Mg stress.

\subsection{Soluble Sugar Concentration in Plant Tissues}

The soluble sugar contents in leaves (Figure 2(a)), stems (Figure 2(b)) and roots (Figure 2(c)) of rice plants were significantly affected by external $\mathrm{Mg}$ concentration and its interaction with $\mathrm{K}$ at day 15 after treatment initiation. 


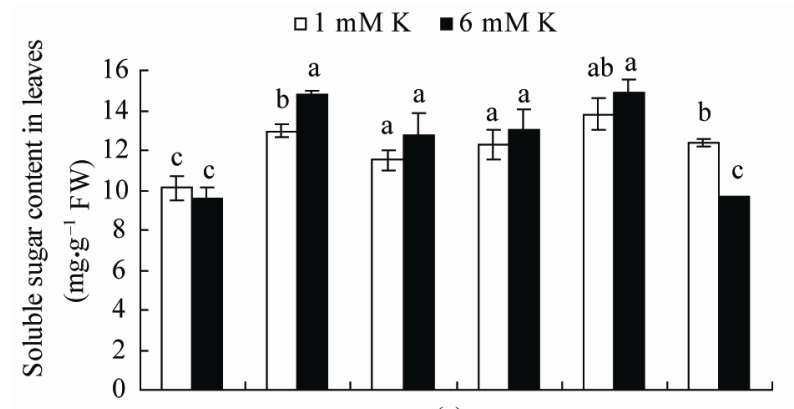

(a)

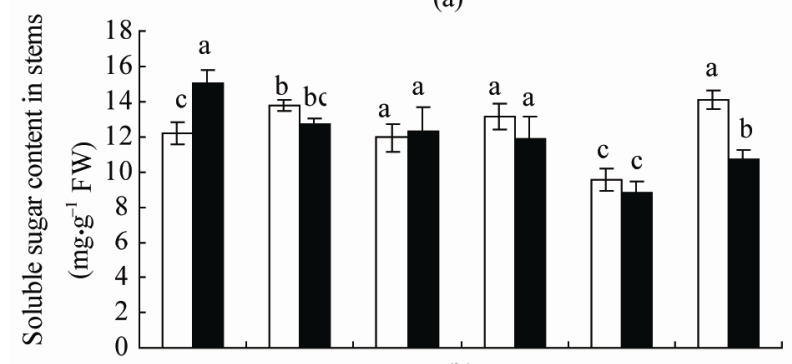

(b)

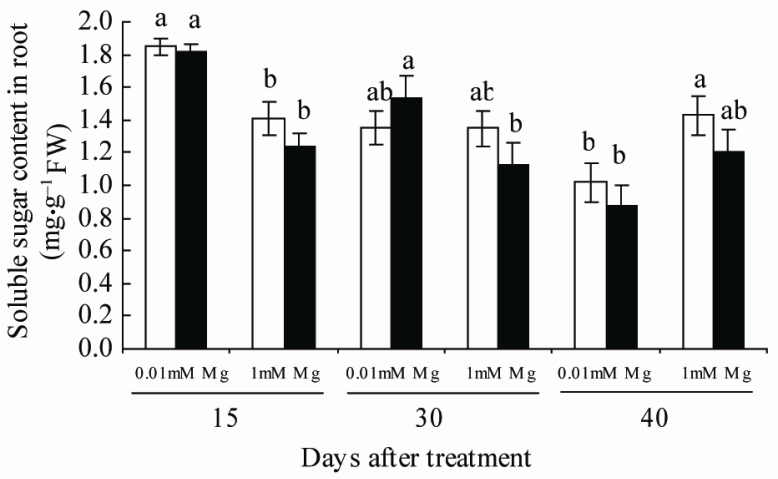

(c)

Figure 2. Effects of the interaction between $\mathrm{Mg}$ and $\mathrm{K}$ on the soluble sugar contents in shoots (a), stems (b) and roots (c) of rice plants after treatment initiation. The nutrient solution contained 0.01 and $1.0 \mathrm{mM}$ Mg concentration, with $K$ at 1.0 and $6.0 \mathrm{mM}$. The vertical bars are the standard error of means of three replicates. Bars with the same small letters at the same harvest mean not significantly difference between treatments by the least significant difference (LSD) at the 0.05 probability level. $\mathrm{Mg}$, magnesium; $\mathrm{K}$, potassium; FW, fresh weight.

When $\mathrm{Mg}$ concentration was $1.81 \mathrm{mg} \cdot \mathrm{g}^{-1} \mathrm{DW}$ in shoots and $0.36 \mathrm{mg} \cdot \mathrm{g}^{-1} \mathrm{DW}$ in roots, the soluble sugar content in leaves was significantly decreased by $35.8 \%$ at $\mathrm{Mg}_{0.01} \mathrm{~K}_{6}$ treatment, as compared with the treatment of $\mathrm{Mg}_{1} \mathrm{~K}_{1}$ (Figure 2(a)) at day 15 after treatment. In contrast to the leaves, the soluble sugar contents in stems and roots were significantly increased by $10.2 \%$ (Figure 2(b)) and 29.2\% (Figure 2(c)), respectively, as compared with the treatment of $\mathrm{Mg}_{1} \mathrm{~K}_{1}$. This result suggested that low $\mathrm{Mg}$ supply with high $\mathrm{K}$ level alters soluble sugar partitioning in different organs of rice plants, particularly increasing the proportion of soluble sugars in the roots. At day 40 after treatment, $\mathrm{Mg}$ concentration in shoots was below the critical deficiency level. Compared with the treatment of $\mathrm{Mg}_{1} \mathrm{~K}_{1}$, the soluble sugar content at $\mathrm{Mg}_{0.01} \mathrm{~K}_{6}$ treatment was significantly increased by $20.8 \%$ in leaves (Figure 2(a)), but decreased by $37.1 \%$ and $39.2 \%$ in stems (Figure 2(b)) and roots (Figure 2(c)), respectively. This result indicated that under $\mathrm{Mg}$ deficiency, soluble sugars may be accumulated in leaves of rice.

\subsection{Plant Growth and Root to Shoot Dry Weight Ratio}

At day 15 after treatment, dry matter yield of both shoots (Figure 3(a)) and roots (Figure 3(b)) in the low-Mg treatment was not significantly different compared to that of the $\mathrm{Mg}_{1} \mathrm{~K}_{1}$ treatment. However, the root to shoot ratio was significantly higher than that of the $\mathrm{Mg}_{1} \mathrm{~K}_{1}$ treatment (Figure 3(c)). At day 30 after treatment, the shoot DW of the $\mathrm{Mg}_{0.01} \mathrm{~K}_{6}$ treatment was reduced by $12.9 \%$ (Figure 3(a)), whereas the root DW increased by $12.1 \%$ (Figure 3(b)) as compared with that of the $\mathrm{Mg}_{1} \mathrm{~K}_{1}$ treatment. The greater decrease in the dry matter of shoots and the marked increase in roots resulted in the increased root to shoot DW ratio (Figure 3(c)) in rice plants. At day 40 after treatment, compared with the $\mathrm{Mg}_{1} \mathrm{~K}_{1}$ treatment, the DW of both shoots and roots of the $\mathrm{Mg}_{0.01} \mathrm{~K}_{6}$ treatment was markedly reduced by $14.7 \%$ (Figure 3(a)) and 12.5\% (Figure 3(b)), respectively, because of $\mathrm{Mg}$ deficiency. The root to shoot ratio did not differ significantly between the $\mathrm{Mg}_{0.01} \mathrm{~K}_{1}$ and $\mathrm{Mg}_{1} \mathrm{~K}_{1}$ treatments (Figure 3(c)). These results revealed that the increase in root to shoot ratio occurred prior to visible $\mathrm{Mg}$ deficiency symptoms in leaves of rice plants.

\subsection{Root Morphology}

In order to study the effects of the interaction between $\mathrm{Mg}$ and $\mathrm{K}$ on root morphology of rice plants, we use a Win-Rhizo LA-1600 Scanner to scan the roots of all treatments of the experiment prior to $\mathrm{Mg}$ deficiency symptoms in rice leaves. The results showed that the total root length (Figure 4(a)), total root surface area (Figure 4(b)), root volume (Figure 4(c)), average root diameter (Figure 4(d)), total length of $0-0.5 \mathrm{~mm}$ diameter roots (Figure 4(e)), and total length of $0.5-1.0 \mathrm{~mm}$ diameter roots (Figure $\mathbf{4 ( f ) ) ~ s i g n i f i c a n t l y ~ i n c r e a s e d ~ b y ~} 11.8 \%$, $16.4 \%, 25.3 \%, 8.1 \%, 16.6 \%$ and $12.5 \%$ respectively for the $\mathrm{Mg}_{0.01} \mathrm{~K}_{6}$ treatment at day 30 after treatment initiation, as compared with the $\mathrm{Mg}_{1} \mathrm{~K}_{1}$ treatment. Under $\mathrm{Mg}$ deficiency at day 40 after treatment, the total root surface area (Figure 4(b)), root volume (Figure 4(c)), average root diameter (Figure 4(d)) were reduced by 10.9\%, 21.1\% 

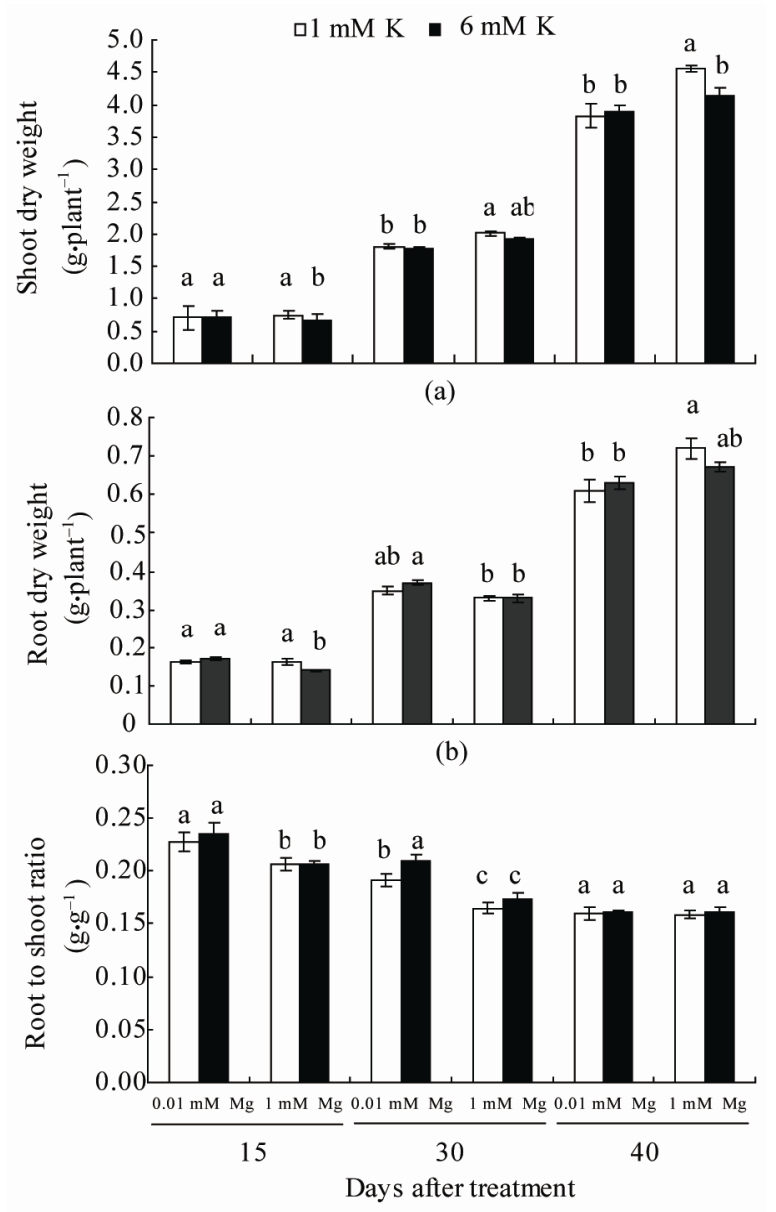

(c)

Figure 3. Effects of the interaction between $\mathrm{Mg}$ and $\mathrm{K}$ on dry matter yield of shoot (a) and root (b), and root to shoot DW ratio (c) of rice plants after treatment initiation. The nutrient solution contained $0.01-1.0 \mathrm{mM}$ Mg concentration, with $\mathrm{K}$ at $1.0-6.0 \mathrm{mM}$. The vertical bars are the standard error of means of three replicates. Bars with the same small letters at the same harvest mean not significantly difference between treatments by the least significant difference (LSD) at the 0.05 probability level. Mg, magnesium; K, potassium; DW, dry weight.

and $11.4 \%$ respectively, except the total length of $0-0.5$ $\mathrm{mm}$ diameter roots (Figure 4(e)), and total length of 0.5 $1.0 \mathrm{~mm}$ diameter roots (Figure $\mathbf{4 ( f )}$ ) were increased by $13.9 \%$ and $5.0 \%$, respectively.

\subsection{Correlation Analysis}

Regression analysis was performed to examine relationships between the soluble sugar contents in roots, root to shoot DW ratio and root morphological parameters of rice plants. Table 1 shows that the soluble sugar contents in leaves at day 15 after treatment initiation had a highly positive correlation with the total root length, total root surface area, root volume, number of root forks, total length of 0 $0.5 \mathrm{~mm}$ and $0.5-1.0 \mathrm{~mm}$ diameter roots and the root to shoot ratio of rice plants at day 30 after treatment initiation. Moreover, these root morphological parameters had a highly positive correlation with the root to shoot ratio at day 30 after treatment initiation. These results indicate that the root to shoot ratio is closely related to the soluble sugar contents in roots and root morphological parameters of rice plants.

\section{Discussion}

In almost all higher plants, the principle end products of leaf photosynthates are sucrose and starch. However, partitioning of sucrose and starch and their effect on dry matter distribution is influenced by several environmental factors, such as low temperature, drought and essential mineral nutrients [18,19]. Mineral nutritional status of plants has a considerable impact on partitioning of carbohydrates and dry matter between shoots and roots $[1,7,20,21]$. It has long been known that deficiencies of essential macronutrients $(\mathrm{N}, \mathrm{P}, \mathrm{K}$ and $\mathrm{Mg}$ ) result in an accumulation of carbohydrates in leaves and roots, and modify the root to shoot biomass ratio [6]. Mg deficiency leads to the accumulation of sugars and starch in young source leaves [8,16,22-25], but they rarely increase their root growth because of impaired export of carbohydrates from source to sink sites [6]. In the present study, $\mathrm{Mg}$ nutritional status had a stronger effect on both root and shoot growth and dry matter distribution of rice plants. At day 30 after treatment initiation, shoot growth for the $\mathrm{Mg}_{0.01} \mathrm{~K}_{6}$ treatment was severely affected by low $\mathrm{Mg}$ stress because the $\mathrm{Mg}$ concentration in shoots was $1.27 \mathrm{mg} \cdot \mathrm{g}^{-1} \mathrm{DW}$ (Figure 1(a)), which was near the critical deficiency level of $1.1 \mathrm{mg} \mathrm{Mg} \cdot \mathrm{g}^{-1} \mathrm{DW}$ [16]. However, the root growth significantly increased (Figure 3(b)) indicating that a considerable proportion of dry matter was partitioned to the roots, leading to an increase in root to shoot DW ratio before $\mathrm{Mg}$ deficiency symptoms were visible in leaves of rice plants (Figure 3(c)). This finding was consistent with that of Hermans et al. [6] who obtained an increase in the root to shoot ratio in Arabidoopsis thaliana plants. We suggest that the increase in root to shoot ratio may be closely associated with the concentrations and distribution of soluble sugars in different tissues of plants because there is a close relationship between shoot to root DW ratios and relative distribution of total carbohydrates in shoots and roots [23]. The increase of root to shoot ratio may be an important adaptive mechanism for rice plants to low-Mg stress before visible $\mathrm{Mg}$ deficiency signs in the leaves. Previous studies suggest that under $\mathrm{Mg}$ deficiencies root growth markedly decreases, leading to an increase in shoot to root DW 


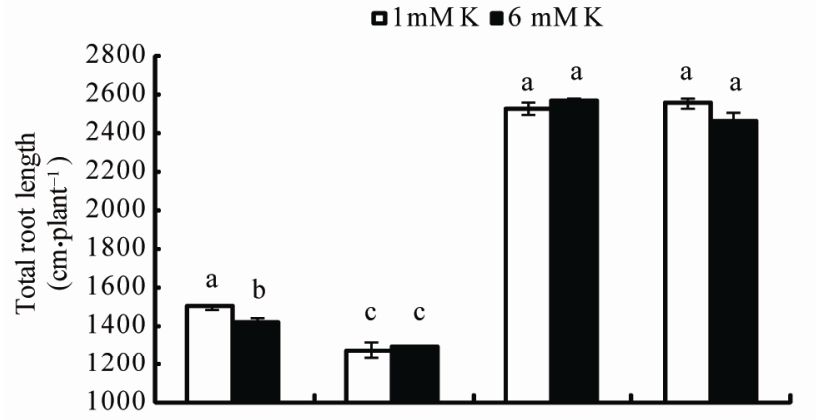

(a)

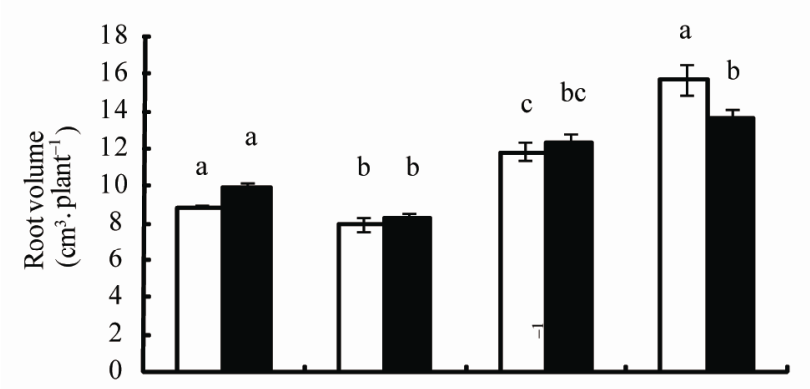

(c)

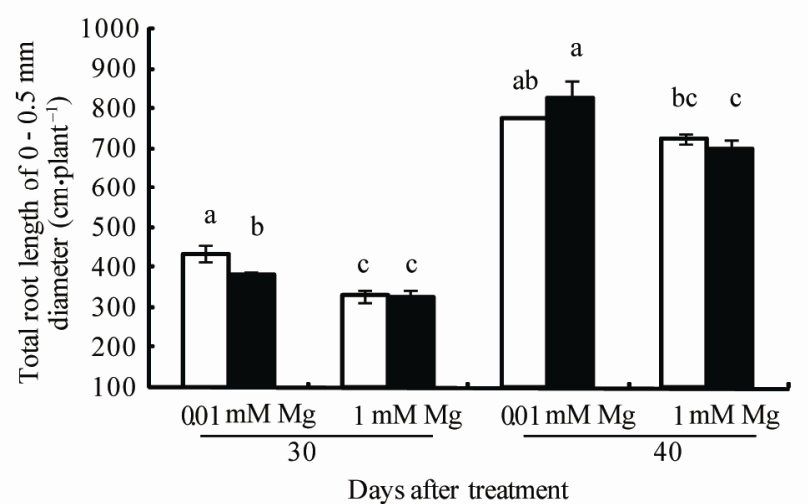

(e)

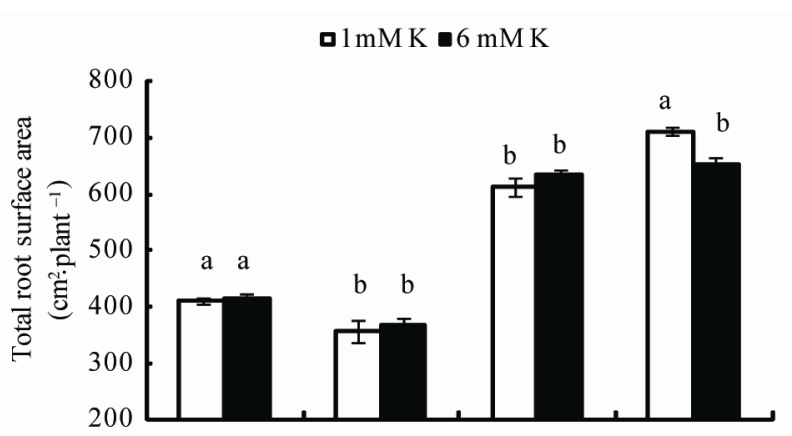

(b)

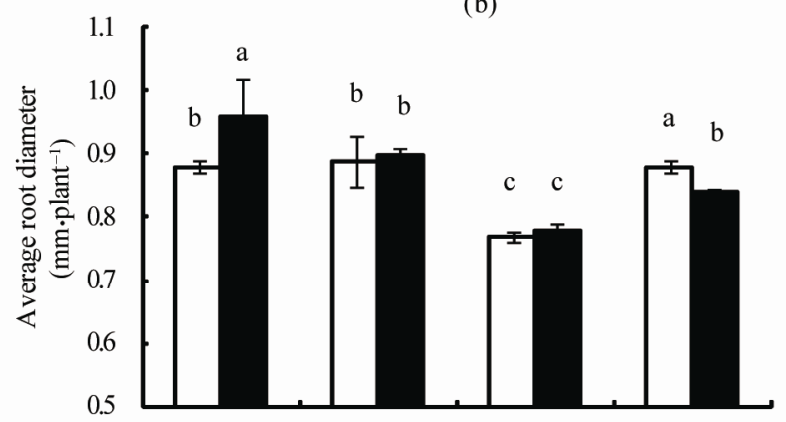

(d)

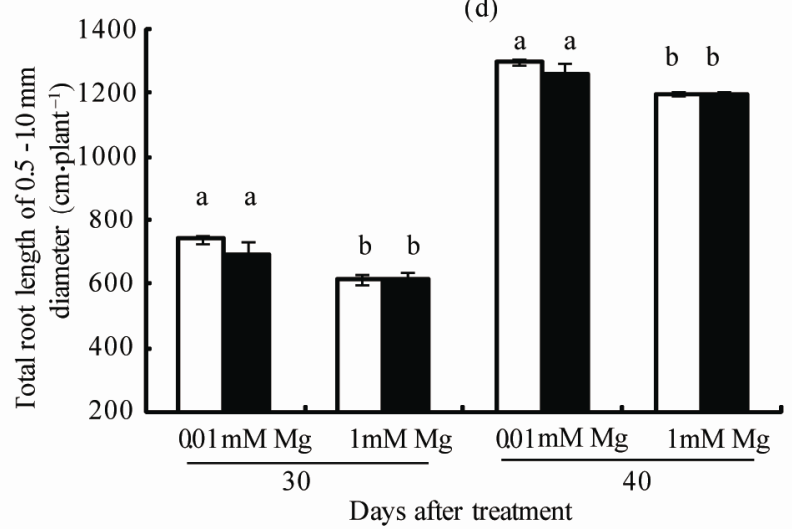

(f)

Figure 4. Effects of the interaction between $\mathrm{Mg}$ and $\mathrm{K}$ on the root morphological parameters of rice plants after treatment initiation. Total root length (a); Total root surface area (b); Root volume (c); Average root diameter (d); Total length of 0 $0.5 \mathrm{~mm}$ diameter roots (e); Total length of $0.5-1.0 \mathrm{~mm}$ diameter roots (f). The nutrient solution contained $0.01-1.0 \mathrm{mM} \mathrm{Mg}$ concentration, with $\mathrm{K}$ at $1.0-6.0 \mathrm{mM}$. The vertical bars are the standard error of means of three replicates. Bars with the same small letters at the same harvest mean not significantly different between treatments by the least significant difference (LSD) at the 0.05 probability level. Mg, magnesium; K, potassium.

ratios in plants [8-11].

Sugars perform important regulatory functions in plants including photosynthesis [26] and carbohydrate partitioning [27,28]. Soluble sugar states have been showed to affect various aspects of physiology and development in higher plants by up- or down-regulating the expression of the relevant genes [26]. In this study, our data showed that the concentration of soluble sugar for the $\mathrm{Mg}_{0.01} \mathrm{~K}_{6}$ treatment at day 15 after treatment was reduced in leaves (Figure 2(a)), but increased in roots
(Figure 2(c)) as compared with the $\mathrm{Mg}_{1} \mathrm{~K}_{1}$ treatment, indicating the increased translocation of sugars to the roots, which might contribute to the increase in root to shoot ratio in rice plants at day 30 after treatment since the growth and development of the root system needs more sugar supply. Furthermore, correlation analysis also revealed that there was a significantly positive linear correlation between the soluble sugar contents in roots of rice plants at day 15 and the root to shoot DW ratio at day 30 after treatment (Table 1). Under Mg deficiency, the 
Table 1. Correlation coefficients between sugar content in root at day 15 and root to shoot ratio and root parameters of rice plants at day 30 after treatment initiation. Rice plants were grown in the nutrient solution contained 0.01 and $1.0 \mathrm{mM} \mathrm{Mg}$ concentration, with $\mathrm{K}$ at 1.0 and $6.0 \mathrm{mM}$. The root parameters of rice were obtained by using a scanner at day 30 after treatment initiation.

\begin{tabular}{ccccccc}
\hline Items & $\begin{array}{c}\text { Total root } \\
\text { length }\end{array}$ & $\begin{array}{c}\text { Total surface } \\
\text { area of root }\end{array}$ & Root volume & $\begin{array}{c}\text { Number of } \\
\text { root forks }\end{array}$ & $\begin{array}{c}\text { Total length of } 0-0.5 \mathrm{~mm} \text { diameter roots } \\
\text { dital length of } 0.5-1\end{array}$ & $\begin{array}{c}\text { Root to shoot } \\
\text { ratio }\end{array}$ \\
\hline $\begin{array}{c}\text { Sugar content in root } \\
\text { at day 15 }\end{array}$ & $0.866^{* *}$ & $0.630^{* *}$ & $0.601^{* *}$ & $0.818^{* *}$ & $0.754^{* *}$ & $0.759^{* *}$ \\
$\begin{array}{c}\text { Root to shoot ratio } \\
\text { at day 30 }\end{array}$ & $0.664^{* *}$ & $0.694^{* *}$ & $0.800^{* *}$ & $0.812^{* *}$ & $0.627^{* *}$ & $0.642^{* *}$ \\
\hline
\end{tabular}

Shown are $R$ values $(\mathrm{n}=12)$, significant differences are indicated by the asterisks $\left({ }^{* *}\right.$ Significant at the 0.01 probability level).

soluble sugar contents in leaves were significantly increased at day 40 after treatment (Figure 2(a)) but markedly reduced in roots (Figure 2(c)) because of impaired export of carbohydrates from leaves to roots. This observation is in agreement with that of Hermans et al. [25]. As the mechanism of sugar regulation involved in carbohydrate metabolism, long-distance transport and partitioning remains unknown, further intensive studies in physiological and molecular level are required.

Root morphology and architecture are the primary traits that influence plant resource acquisition [29]. Root growth requires nutrients that are absorbed from the external culture medium and photosynthates that are transported from the shoot. It is evident that sugar supply is one of the most important factors limiting growth of the root system [30]. Hermans et al. [6] suggest that root morphology alterations are closely related to the regulation of sugars and hormones in plants. The results in Figure 4 indicate that the enhanced total root length (Figure 4(a)), total surface area (Figure 4(b)), root volume (Figure 4(c)), average root diameter (Figure 4(d)) and total length of $0-0.5 \mathrm{~mm}$ (Figure 4(e)) and 0.5 - $1.0 \mathrm{~mm}$ diameter roots (Figure 4(f)) may be related to enhanced concentration of soluble sugars in roots of rice at day 15 after treatment initiation. The correlation analysis indicated that the root to shoot ratio is closely related to the soluble sugar contents in roots and root morphological parameters of rice plants (Table 1).

In conclusion, low $\mathrm{Mg}$ with high $\mathrm{K}$ supply alters soluble sugar partitioning and root morphological parameters, restrains shoot growth but enhances root growth, and thereby increases root/shoot DW ratio before visible $\mathrm{Mg}$ deficiency symptoms appear in rice leaves. These responses may represent a primary adaptive mechanism for rice plants to $\mathrm{Mg}$ stress during the early growth stage.

\section{Acknowledgements}

We thank Professor Richard M. Cruse and Heidi Asbjornsen of Iowa State University for their critically read- ing and correcting the English language of the manuscript. This research was financially supported in part by the Dead Sea Works Ltd., Israel.

\section{REFERENCES}

[1] H. Marschner, "Mineral Nutrition of Higher Plants," 2nd Edition, Academic Press, London, 1995.

[2] O. Shaul, "Magnesium Transport and Function in Plants: the Tip of the Iceberg," Biometals, Vol. 15, No. 3, September 2002, pp. 309-323. doi:10.1023/A:1016091118585

[3] S. Shabala and Y. Hariadi, "Effects of Magnesium Availability on the Activity of Plasma Membrane Ion Transporters and Light-Induced Responses from Broad Bean Leaf Mesophyll," Planta, Vol. 221, No. 1, April 2005, pp. 56-65. doi:10.1007/s00425-004-1425-0

[4] C. Hermans, F. Bourgis, M. Faucher, R. J. Strasser, S. Delrot and N. Verbruggen, "Magnesium Deficiency in Sugar Beets Alters Sugar Partitioning and Phloem Loading in Young Mature Leaves," Planta, Vol. 220, No. 4, October 2005, pp. 541-549. doi:10.1007/s00425-004-1376-5

[5] K. Mengel and E. A. Kirkby, "Principles of Plant Nutrition," 4th Edition, International Potash Institute, Switzerland, 1987.

[6] C. Hermans, J. P. Hammond, P. J. White and N. Verbruggen, "How Do Plants Respond to Nutrient Shortage by Biomass Allocation?" Trends in Plant Science, Vol. 11, No. 12, December 2006, pp. 610-617. doi:10.1016/j.tplants.2006.10.007

[7] H. Marschner, E. A. Kirkby and I. Cakmak, "Effect of Mineral Nutritional Status on Shoot-Root Partitioning of Photoassimilates and Cycling of Mineral Nutrients," Journal of Experimental Botany, Vol. 47, No. Special Issue, August 1996, pp. 1255-1263.

doi:10.1093/jxb/47.Special-Issue. 1255

[8] I. Cakmak, C. Hengeler and H. Marschner, "Partitioning of Shoot and Root Dry Matter and Carbohydrates in Bean Plants Suffering from Phosphorus, Potassium and MagneSium Deficiency," Journal of Experimental Botany, Vol. 45, No. 9, September 1994, pp. 1245-1250. 
[9] T. Ericsson, "Growth and Shoot: Root Ratio of Seedlings in Relation to Nutrient Availability," Plant and Soil, Vol. 168-169, No. 1, 1995, pp. 205-214.

[10] C. Hermans, G. N. Johnson, R. J. Strasser and N. Verbruggen, "Physiological Characterization of Magnesium Deficiency in Sugar Beet: Acclimation to Low Magnesium Differentially Affects Photosystems I and II," Planta, Vol. 220, No. 2, 2004, pp. 344-355. doi:10.1007/s00425-004-1340-4

[11] R. K. Tewari, P. Kumar and P. N. Sharma, "Magnesium Deficiency Induced Oxidative Stress and Antioxidant Responses in Mulberry Plants," Scientia Horticulturae, Vol. 108, No. 1, March 2006, pp. 7-14. doi:10.1016/j.scienta.2005.12.006

[12] N. K. Fageria, "Dry Matter Yield and Nutrient Uptake by Lowland Rice at Different Growth Stages," Journal of Plant Nutrition, Vol. 27, No. 6, 2004, pp. 947-958.

[13] S. Yoshida, D. A. Forno, G. H. Cock and K. A. Gomez, "Laboratory Manual for Physiological Studies of Rice," 2nd Edition, International Rice Research Institute, Los Banos, 1972.

[14] J. R. Lowther, "Use of a Single Sulphuric-Hydrogen Peroxide Digest for the Analysis of Pinus radiate Needles," Communications in Soil Science and Plant Analysis, Vol. 11, No. 2, 1980, pp. 175-188.

[15] L. Villarreal-Ruiz, I. C. Anderson and I. J. Alexander, "Interaction between an Isolate from the Hymenoscyphus Ericae Aggregate and Roots of Pinus and Vaccinium," New Phytologist, Vol. 164, No. 1, October 2004, pp. 183192. doi:10.1111/j.1469-8137.2004.01167.x

[16] Y. Ding, W. Luo and G. Xu, "Characterization of Magnesium Nutrition and Interaction of Magnesium and Potassium in Rice," Annals of Applied Biology, Vol. 149, No. 2, October 2006, pp. 111-123. doi:10.1111/j.1744-7348.2006.00080.x

[17] T. Ohno and D. L. Grunes, "Potassium-Magnesium Interaction Affecting Nutrient Uptake by Wheat Forage," Soil Science Society of America Journal, Vol. 49, No. 3, 1985, pp. 685-690.

[18] S. C. Huber, "Biochemical Mechanism for Regulation of Sucrose Accumulation in Leaves during Photosynthesis," Plant physiology, Vol. 91, No. 2, October 1989, pp. 656662.

[19] I. A. Wardlaw, "The Control of Carbon Partitioning in Plants," New Phytologist, Vol. 116, No. 3, November 1990, pp. 341-381.

[20] U. Druege, S. Zerche, R. Kadner and M. Ernst, "Relation between Nitrogen Status, Carbohydrate Distribution and
Subsequent Rooting of Chrysanthemum Cuttings as Affected by Pre-Harvest Nitrogen Supply and Coldstorage," Annals of Botany, Vol. 85, No. 5, May 2000, pp. 687-701. doi:10.1006/anbo.2000.1132

[21] J. López-Bucio, A. Cruz-Ramirez and L. Herrera-Estrella, "The Role of Nutrient Availability in Regulating Root Architecture," Current Opinion in Plant Biology, Vol. 6, No. 3, Jun 2003, pp. 280-287. doi:10.1016/S1369-5266(03)00035-9

[22] I. Cakmak and H. Marschner, "Magnesium Deficiency and High Light Intensity Enhance Activities of Superoxide Dismutase, Ascorbate Peroxidase, and Glutathione Reductase in Bean Leaves," Plant Physiology, Vol. 98, No. 4, April 1992, pp. 1222-1227.

[23] I. Cakmak, C. Hengeler and H. Marschner, "Changes in Phloem Export of Sucrose in Leaves in Response to Phosphorus, Potassium and Magnesium Deficiency in Bean Plants," Journal of Experimental Botany, Vol. 45, No. 9, September 1994, pp. 1251-1257.

[24] E. S. Fischer, G. Lohaus, D. Heineke and H. W. Heldt, "Magnesium Deficiency Results in Accumulation of Carbohydrates and Amino Acids in Source and Sink Leaves of Spinach," Physiologia Plantarum, Vol. 102, No.1, January 1998, pp. 16-20.

[25] C. Hermans and N. Verbruggen, "Physiological Characterization of $\mathrm{Mg}$ Deficiency in Arabidopsis Thaliana," Journal of Experimental Botany, Vol. 56, No. 418, August 2005, pp. 2153-2161. doi:10.1093/jxb/eri215

[26] F. Rolland, B. Moore and J. Sheen, "Sugar Sensing and Signaling in Plants," The Plant Cell, Vol. 14, No. Supply, May 2002, pp. 185-205. doi:10.1105/tpc.010455

[27] T. J. Chiou and D. R. Bush, "Sucrose Is a Signal Molecule in Assimilate Partitioning," Proceedings of the National Academy of Sciences of the United States of America, Vol. 95, No. 8, April 1998, pp. 4784-4788.

[28] F. Rook and M. W. Bevan, "Genetic Approaches to Understanding Sugar-Response Pathways," Journal of Experimental Botany, Vol. 54, No. 382, January 2003, pp. 495-501. doi:10.1093/jxb/erg054

[29] H. Wang, Y. Inukai and A. Yamauchi, "Root Deveiopment and Nutrient Uptake," Critical Reviews in Plant Sciences, Vol. 25, No. 3, May 2006, pp. 279-301. doi:10.1080/07352680600709917

[30] W. R. John, L. P. Linda and R. S. Charles, "Partitioning of Sugar between Growth and Nitrate Reduction in Cotton Roots," Plant Physiology, Vol. 62, No. 4, October 1978, pp. 550-553. 